\title{
PENGARUH KOMUNIKASI PELAYANAN DAN KEPUASAN TERHADAP LOYALITAS PELANGGAN DI 7-ELEVEN BUARAN
}

\author{
Jerry Marcellinus Logahan; Yohana Tiara Eka Putri \\ Management Department, School of Business Management, BINUS University \\ Jln. K. H. Syahdan No. 9, Palmerah, Jakarta Barat 11480 \\ jerrymarcellinus@yahoo.com
}

\begin{abstract}
This research was motivated by low communication in the business retail in terms of service from employees to customers. It influences the decline in customer satisfaction and leads to customer loyalty at a very low level. This study aims to identify and analyze the significance of the influence of customer service $\left(X_{1}\right)$ and customer satisfaction $\left(X_{2}\right)$ on customer loyalty $(Y)$. Research was conducted in February - May 2013 held at 7Eleven Buaran Jakarta. Research used quantitative method by using questionnaires filled directly by the visitors of 7-Eleven Buaran with a population of 19.920 people and a sample of 100 people, calculated using the Slovin formula. Validity test, reliability, normality, correlation, regression, hypothesis, and the determination carried out in this study using the data processed using SPSS (Statistical Product and Service Solutions) version 16.0. Results indicated that customer service has significant influence by $14.6 \%$ on customer loyalty, customer satisfaction has a significant effect of $8.5 \%$ on customer loyalty, and customer service and customer satisfaction have significant influence amounted to $15,2 \%$. Thus, this study showed that customer service and customer satisfaction have a significant effect on customer loyalty in 7-eleven Buaran Jakarta.
\end{abstract}

Keywords: communication, customer service, customer satisfaction, customer loyalty

\begin{abstract}
ABSTRAK
Penelitian ini dilatarbelakangi komunikasi dalam bisnis ritel yang rendah dalam hal pelayanan dari karyawan kepada para pelanggan. Hal tersebut memengaruhi turunnya kepuasan pelanggan dan menyebabkan loyalitas pelanggan berada pada tingkat yang sangat rendah. Penelitian bertujuan untuk mengetahui dan menganalisis seberapa signifikan pengaruh pelayanan pelanggan $\left(X_{1}\right)$ dan kepuasan pelanggan $\left(X_{2}\right)$ terhadap loyalitas pelanggan (Y). Penelitian dilaksanakan pada bulan Februari - Mei 2013 bertempat di 7-Eleven Buaran, Jln. Buaran Indah Raya No. 104 - 106, Jakarta Timur 13470. Metode penelitian yang digunakan dalam penelitian ini adalah kuantitatif dengan menggunakan kuesioner yang diisi langsung oleh para pengunjung 7Eleven Buaran dengan jumlah populasi 19.920 orang dan sampel sebanyak 100 orang dihitung menggunakan rumus Slovin. Uji validitas, reliabilitas, normalitas, korelasi, regresi, hipotesis, dan determinasi dilakukan dalam penelitian ini menggunakan data yang diolah dengan menggunakan program SPSS (Statistical Product and Service Solution) versi 16.0. Hasil penelitian ini menunjukkan bahwa pelayanan pelanggan memiliki pengaruh signifikan sebesar 14,6\% terhadap loyalitas pelanggan, kepuasan pelanggan memiliki pengaruh signifikan sebesar 8,5\% terhadap loyalitas pelanggan, serta pelayanan pelanggan dan kepuasan pelanggan memiliki pengaruh signifikan sebesar 15,2\%. Dengan demikian, penelitian ini menunjukkan bahwa pelayanan pelanggan dan kepuasan pelanggan berpengaruh signifikan terhadap loyalitas pelanggan.
\end{abstract}

Kata kunci: komunikasi, pelayanan pelanggan, kepuasan pelanggan, loyalitas pelanggan 


\section{PENDAHULUAN}

Komunikasi tidak pernah lepas dari kehidupan sehari-hari. Proses komunikasi pada hakikatnya adalah proses penyampaian pikiran atau perasaan oleh seseorang (komunikator) kepada orang lain (komunikan). Hovland dalam Effendy (2007) mendefinisikan ilmu komunikasi sebagai upaya yang sistematis untuk merumuskan secara tegar asas-asas penyampaian informasi serta pembentukan pendapat dan sikap. Definisi Hovland tersebut menunjukkan bahwa yang dijadikan objek studi ilmu komunikasi bukan saja penyampaian informasi, melainkan juga pembentukan pendapat umum (public opinion) dan sikap publik (public attitude) yang dalam kehidupan sosial dan kehidupan politik memainkan peranan yang amat penting. Pembentukan sikap publik tersebut dapat berupa timbulnya loyalitas seseorang kepada suatu bisnis ritel

Loyalitas pelanggan didefinisikan sebagai pelanggan puas terhadap produk atau merek yang dikonsumsi atau dipakai, dan akan membeli ulang produk tersebut (Sumarwan, 2011). Loyalitas pelanggan memiliki tingkat retensi yang tinggi, komitmen terhadap porsi belanja ke perusahaan dalam kategori produknya, dan bersedia menjadi pemberi rekomendasi kepada koleganya agar menjadi pelanggan perusahaan (Sumarwan, 2011). Dua kondisi penting yang berhubungan dengan loyalitas adalah retensi pelanggan, yang menjelaskan lamanya hubungan dengan pelanggan, dan total pangsa pelanggan, yang menjelaskan persentase dari anggaran pelanggan yang dibelanjakan kepada perusahaan tersebut. Loyalitas merupakan hasil dari mencurahkan perhatian pada hal yang perlu dilakukan untuk mempertahankan pelanggan dan kemudian terus-menerus melakukannya.

Pentingnya loyalitas pelanggan dalam pemasaran adalah mutlak. Pelanggan yang loyal akan menjadi aset yang sangat bernilai bagi perusahaan. Selain itu, pelanggan yang loyal akan memberikan umpan balik yang positif kepada perusahaan. Pelanggan yang loyal akan tidak sensitif dengan harga, melakukan pembelian berulang, dan menjadi penganjur kepada koleganya. Sikap pelanggan tersebut diwujudkan dalam interaksinya dengan toko ritel yang dikunjunginya.

Ritel merupakan mata rantai yang penting dalam proses distribusi barang dan merupakan mata rantai terakhir dalam suatu proses distribusi (Soliha, 2008). Melalui ritel, suatu produk dapat bertemu langsung dengan penggunanya. Seiring dengan perkembangan bisnis ritel, pada saat ini bisnis ritel tidak lagi dikelola secara tradisional, melainkan dengan cara modern sehingga menjadi bisnis yang inovatif, dinamis, dan kompetitif. Persaingan yang ketat di bisnis ritel tidak terlepas dari makin menjamurnya pusat-pusat perbelanjaan baik yang bersifat lokal, nasional, maupun internasional dengan berbagai skala dan segmen yang dibidik.

Bisnis ritel makin berkembang pesat di Indonesia beberapa tahun belakangan ini. Masyarakat perkotaan kini dimanjakan oleh kehadiran berbagai pusat perbelanjaan. Bahkan lokasinya kadangkadang di satu kawasan. Kondisi ini sangat menguntungkan karena masyarakat tinggal memilih gerai mana yang akan dimasuki. Bisnis ritel dapat pula dibagi menjadi tiga kelompok usaha perdagangan eceran, yaitu grosir (pedagang besar), pengecer besar atau menengah, dan minimarket modern. Semua kelompok usaha bisnis ritel tersebut tidak hanya bisnis ritel lokal, tetapi dengan adanya era perdagangan bebas ASEAN (AFTA) memengaruhi terjadinya perubahan dalam industri ritel yaitu dengan masuknya peritel asing dalam pasar Indonesia, contohnya 7-Eleven.

7-Eleven (7-eleven, 2013) adalah toko ritel terbesar dengan hampir 49.500 toko di 16 negara, di antaranya lebih dari 10.000 di Amerika Utara. 7-Eleven berfokus pada pemenuhan kebutuhan dan kenyamanan, berorientasi pada konsumen dengan menyediakan produk dan layanan berkualitas tinggi dengan harga yang terjangkau, transaksi cepat serta ramah lingkungan. Tidak heran 7-Eleven selalu ramai dikunjungi orang-orang dari berbagai kalangan. Hal itu juga berlaku di Jakarta, yang di setiap cabang 7-Eleven selalu ramai setiap harinya, khususnya di cabang Buaran Jakarta. 
Meskipun selalu ramai dikunjungi, ternyata masih terdapat beberapa keluhan dari para pengunjung 7-Eleven Buaran Jakarta. Keluhan yang paling banyak ditemui dari 100 responden adalah karyawan kurang ramah, karyawan kurang tanggap dalam membersihkan meja, fasilitas yang disediakan (meja, kursi, toilet) kotor dan tidak nyaman, terlalu banyak menu sehingga membuat pelanggan bingung, dan kurangnya instruksi penyediaan minuman sehingga pengunjung baru tidak tahu cara membuat minumannya sendiri. Dari keluhan-keluhan ini, ditemui "intensitas berkunjung ke 7-Eleven tidak terlalu sering, maksimal satu kali dalam seminggu, bahkan berkunjung kalau hanya ada urusan dengan orang lain" dan "pelanggan jarang membeli produk buatan 7-Eleven karena harganya lebih mahal daripada produk lain". Sehingga yang menjadi pertanyaan dalam penelitian ini adalah pengaruh pelayanan dan kepuasan terhadap loyalitas pelangggan di 7-eleven Buaran Jakarta.

\section{Tinjauan Literatur}

Pada umumnya, komunikasi melibatkan dua orang atau lebih, dan proses penyampaian pesan dapat dilakukan dengan menggunakan cara-cara berkomunikasi yang biasa dilakukan oleh seseorang melalui lisan, tulisan, maupun sinyal-sinyal nonverbal. Lasswell dalam Mulyana (2008) mengatakan bahwa cara terbaik untuk menggambarkan komunikasi adalah menjawab pertanyaan-pertanyaan berikut: Who Says What In Which Channel To Whom With What Effect? atau Siapa Mengatakan Apa

Dengan Saluran Apa Kepada Siapa Dengan Pengaruh Bagaimana? Paradigma Lasswell ini menunjukkan bahwa komunikasi meliputi lima unsur sebagai jawaban dari pertanyaan yang diajukan itu, yaitu: komunikator, pesan, media, komunikan, dan efek. Jadi, berdasarkan paradigma Lasswell tersebut, komunikasi adalah proses penyampaian pesan oleh komunikator kepada komunikan melalui media yang menimbulkan efek tertentu.

Menurut Himstreet dan Baty (Purwanto, 2006), komunikasi adalah suatu proses pertukaran informasi antarindividu melalui suatu sistem yang biasa (lazim), baik dengan simbol-simbol, sinyalsinyal, maupun perilaku atau tindakan. Sementara itu, komunikasi bisnis (Purwanto, 2006) adalah komunikasi yang digunakan dalam dunia bisnis yang mencakup berbagai macam bentuk komunikasi, baik komunikasi verbal maupun komunikasi nonverbal untuk mencapai tujuan tertentu. Dalam dunia bisnis, seorang komunikator yang baik di samping harus memiliki kemampuan berkomunikasi yang baik, juga harus mampu menggunakan berbagai macam alat atau media komunikasi yang ada untuk menyampaikan pesan-pesan bisnis kepada pihak lain secara efektif dan efisien, sehingga tujuan penyampaian pesan-pesan bisnis dapat tercapai. Komunikasi bisnis tersebut berkaitan erat dengan komunikasi pemasaran (marketing communication).

Komunikasi pemasaran (Shim, 2003) merepresentasikan gabungan semua unsur dalam bauran pemasaran merek, yang memfasilitasi terjadinya pertukaran dengan menciptakan suatu arti yang disebarluaskan kepada pelanggan atau kliennya. Komunikasi pemasaran dapat berupa pakaian yang dikenakan oleh seorang tenaga penjual, katalog harga, produk dan jasa layanan, serta kantor perusahaan. Dari sudut pandang manajer pemasaran, komunikasi pemasaran memiliki tujuan-tujuan sebagai berikut (Peter \& Olson, 2000): konsumen harus memiliki kebutuhan yang disadari akan suatu kategori produk atau bentuk produk; konsumen harus sadar akan merek; konsumen harus memiliki pemahaman terhadap merek yang positif; konsumen harus memiliki keinginan untuk membeli merek tertentu; konsumen harus melakukan berbagai macam perilaku untuk membeli merek tertentu.

Komunikasi antarpribadi (interpersonal communication) adalah komunikasi antara orangorang secara tatap muka, yang memungkinkan setiap orang menangkap reaksi orang lain secara langsung, baik secara verbal maupun nonverbal (Mulyana, 2008). Bentuk khusus dari komunikasi antarpribadi adalah komunikasi diadik yang melibatkan hanya dua orang. Ciri-ciri komunikasi diadik adalah pihak-pihak yang berkomunikasi berada dalam jarak yang dekat dan pihak-pihak yang berkomunikasi mengirim dan menerima pesan secara simultan dan spontan, baik secara verbal maupun nonverbal 
Keberhasilan komunikasi menjadi tanggung jawab para pihak yang berkomunikasi. Komunikasi antarpribadi sangat potensial untuk memengaruhi atau membujuk orang lain, karena kita dapat menggunakan alat indera (penglihatan, pendengaran, sentuhan, penciuman, pengecap) untuk mempertinggi daya bujuk pesan kita. Sebagai komunikasi yang paling lengkap dan paling sempurna, komunikasi antarpribadi berperan penting hingga kapan pun, selama manusia masih memiliki emosi.

Salah satu teori komunikasi antarpribadi yang digunakan dalam penelitian ini adalah Teori Pertukaran Sosial (Social Exchange Theory) dari Thibaut dan Kelley. Teori pertukaran sosial didasarkan pada ide bahwa orang memandang hubungan mereka dalam konteks ekonomi (Thibaut \& Kelley, 1959). Mereka menghitung pengorbanan dan membandingkannya dengan penghargaan yang didapatkan dengan meneruskan hubungan itu. Pengorbanan (cost) adalah elemen dari sebuah hubungan yang memiliki nilai negatif bagi seseorang. Sedangkan penghargaan (rewards) adalah elemen-elemen dalam sebuah hubungan yang memiliki nilai positif.

Para teoretikus pertukaran sosial berpendapat bahwa semua orang menilai hubungan mereka dengan melihat pengorbanan dan penghargaan. Sudut pandang pertukaran sosial berpendapat bahwa orang menghitung nilai keseluruhan dari sebuah hubungan dengan mengurangkan pengorbanannya dari penghargaan yang diterima (West, 2008). Hubungan yang positif adalah hubungan yang nilainya merupakan angka positif; penghargaan lebih besar daripada pengorbanan. Hubungan yang nilainya adalah angka negatif (pengorbanan melebihi penghargaan) cenderung negatif untuk para partisipannya. Teori pertukaran sosial bahkan melangkah lebih jauh dengan memprediksikan bahwa nilai (worth) dari sebuah hubungan memengaruhi hasil akhir (outcome) atau apakah orang akan meneruskan suatu hubungan atau mengakhirinya. Hubungan yang positif bisanya dapat bertahan, sedangkan hubungan yang negatif mungkin akan berakhir.

Teori ini memiliki asumsi pertukaran sosial mengenai sifat dasar manusia, yaitu: (1) Manusia mencari penghargaan dan menghindari hubungan. Pendekatan ini berasumsi bahwa perilaku orang dimotivasi oleh suatu mekanisme dorongan internal. Ketika orang merasakan dorongan ini, mereka termotivasi untuk menguranginya, dan proses pelaksanaanya merupakan hal yang menyenangkan. (2) Manusia adalah makhluk rasional. Teori ini didasrkan pada pemikiran bahwa di dalam batasan-batasan informasi yang tersedia untuknya, manusia akan menghitung pengorbanan dan penghargaan dari sebuah situasi tertentu dan ini akan menentukan perilakunya. (3) Standar yang digunakan manusia untuk mengevaluasi pengorbanan dan penghargaan bervariasi seiring berjalannya waktu dari satu orang ke orang lainnya. Hal ini menunjukkan bahwa teori ini harus mempertimbangkan adanya keanekaragaman. Tidak ada satu standar yang dapat diterapkan pada semua orang untuk menentukan apa pengorbanan dan apa penghargaan itu.

Kaitan antara teori pertukaran sosial dengan penelitian ini dapat dilihat dari sisi pelanggan. Para pelanggan pasti selalu ingin mendapatkan penghargaan atau dalam hal ini adalah keuntungan yang mereka dapatkan setelah berkunjung serta mengonsumsi produk dan jasa 7-Eleven Buaran. Jika pelanggan mendapatkan keuntungan yang banyak dari 7-Eleven Buaran, seperti mendapatkan paket menu yang murah, potongan harga pada menu tertentu, dapat menikmati fasilitas yang lengkap dan nyaman, serta keluhan selalu ditanggapi dan diselesaikan dengan baik oleh pihak 7-Eleven Buaran, pelanggan akan merasa puas dan loyal serta mereka akan melanjutkan hubungannya dengan 7-Eleven Buaran dengan cara kunjungan kembali. Namun jika pelanggan tidak mendapatkan semua keuntungan yang telah disebutkan itu dan pengorbanan mereka untuk berkunjung serta menikmati produk dan jasa 7-Eleven Buaran lebih besar, dapat dipastikan pelanggan tidak akan merasa puas dan tidak akan meneruskan hubungannya atau tidak akan kembali lagi ke 7-Eleven Buaran.

Model stimulus - respons (S - R) dapat menggambarkan konsep komunikasi antarpribadi. Model ini menunjukkan komunikasi sebagai proses aksi - reaksi yang sangat sederhana. Model $\mathrm{S}-\mathrm{R}$ (Mulyana, 2008) mengasumsikan bahwa kata-kata verbal, isyarat-isyarat nonverbal, gambar-gambar, dan tindakan-tindakan tertentu akan merangsang orang lain untuk memberikan respons dengan cara 
tertentu. Oleh karena itu, proses ini dapat dianggap sebagai pertukaran atau pemindahan informasi atau gagasan. Proses ini dapat bersifat timbal-balik dan mempunyai banyak efek. Setiap efek dapat mengubah tindakan komunikasi berikutnya.

Model S - R mengabaikan komunikasi sebagai suatu proses, khususnya yang berkenaan dengan faktor manusia. Secara implicit terdapat asumsi dalam model $\mathrm{S}-\mathrm{R}$ ini bahwa perilaku (respons) manusia dapat diramalkan. Ringkasnya, komunikasi dianggap statis; manusia dianggap berperilaku karena kekuatan dari luar (stimulus), bukan berdasarkan kehendak, keinginan, atau kemauan bebasnya.

Model ini berkaitan dengan penelitian dengan pihak 7-Eleven sebagai komunikator memberikan stimulus-stimulus kepada pelanggan dalam hal pelayanan dengan berbagai bentuk, seperti memberikan satu potong ayam goreng jika membeli satu paket menu makanan ayam goreng dan nasi, menyediakan minuman dengan berbagai warna dan rasa yang tidak ada di toko-toko lain, menggunakan pencahayaan gedung yang terang dan warna-warna cerah, serta menyuguhkan bentuk pelayanan kafetaria sehingga pelanggan dapat bebas menikmati produk-produk yang dijual di 7Eleven Buaran dalam waktu lama. Selain pelayanan yang diberikan pihak 7-Eleven Buaran tersebut, kepuasan dari diri pelanggan akan pelayanan-pelayanan yang diberikan 7-Eleven Buaran dapat juga menjadi stimulus yang menentukan apakah pelanggan akan kembali lagi mengunjungi dan melakukan pembelian di 7-Eleven Buaran Jakarta.

Sedangkan pelanggan sebagai komunikan, juga memberikan respons berupa sikap loyal mereka terhadap 7-Eleven Buaran, seperti melakukan pembelian produk kembali, mengajak orang lain untuk berkunjung ke 7-Eleven Buaran, tetap mengunjungi 7-Eleven Buaran meskipun terdapat toko pesaing baru, serta memberikan saran dan kritik secara langsung kepada pihak 7-Eleven Buaran.

Loyalitas pelanggan secara umum dapat diartikan kesetiaan seseorang atas suatu produk, baik barang maupun jasa tertentu. Menurut Griffin (2005) loyalitas pelanggan adalah komitmen untuk bertahan secara mendalam untuk melakukan pembelian ulang atau berlangganan kembali produk atau jasa terpilih secara konsisten pada masa yang akan datang, meskipun pengaruh situasi dan usaha-usaha pemasaran mempunyai potensi untuk menyebabkan perubahan perilaku. Sementara menurut Sumarwan et al (2011), loyalitas pelanggan didefinisikan sebagai pelanggan yang merasa puas terhadap produk atau merek yang dikonsumsi atau dipakai, dan akan membeli ulang produk tersebut.

Kepuasan tidak hanya diperoleh pada saat mendapatkan suatu barang yang dibeli, tetapi juga dipengaruhi oleh pelayanan. Menurut Kotler (Laksana, 2008), pelayanan adalah setiap tindakan atau kegiatan yang dapat ditawarkan oleh suatu pihak kepada pihak lain, yang pada dasarnya tidak berwujud dan tidak mengakibatkan kepemilikan apapun. Pelayanan pelanggan dapat disebut sebagai proses pemenuhan kebutuhan, yaitu proses untuk memenuhi permintaan pelanggan secara keseluruhan (Siagian, 2005). Sedangkan menurut Lupiyoadi (2006), pelayanan pelanggan didefinisikan sebagai aktivitas di seluruh area bisnis yang berusaha mengombinasikan antara penjualan jasa untuk memenuhi kepuasan pelanggan mulai dari pemesanan, pemrosesan, hingga pemberian hasil jasa melalui komunikasi demi mempererat kerjasama dengan pelanggan.

Untuk mencapai kinerja yang tinggi dalam pelayanan pelanggan, manajemen perusahaan jasa juga harus menyiapkan sumber daya manusia melalui training tentang cara menghadapi permintaan pelanggan, mengadakan komunikasi personal yang memberikan kesempatan bekerja sama dengan kualitas yang lebih baik. Pelayanan pelanggan jika dilakukan secara efektif dapat menimbulkan perubahan yang signifikan dalam menciptakan permintaan dan mempertahankan kesetiaan pelanggan.

Kepuasan merupakan salah satu kriteria utama dalam upaya untuk mempertahankan konsumen yang telah ada ataupun untuk menarik konsumen yang baru. Mowen dalam Tjiptono (2007) merumuskan kepuasan pelanggan sebagai sikap keseluruhan terhadap suatu barang atau jasa setelah 
perolehan dan pemakaiannya. Menurut Supranto (2006), kepuasan pelanggan adalah tingkat perasaan pelanggan setelah membandingkan kinerja yang dirasakan dengan harapannya. Harapan pelanggan dapat dibentuk dari pengalaman masa lalu, komentar dari kerabat serta janji dan informasi pemasar dan saingannya.

\section{METODE PENELITIAN}

Metode yang digunakan dalam penelitian ini adalah kuantitatif dengan menggunakan kuesioner yang diisi langsung para pengunjung 7-Eleven Buaran dengan jumlah populasi 19.920 orang dan sampel sebanyak 100 orang dihitung menggunakan rumus Slovin. Uji validitas, reliabilitas, normalitas, korelasi, regresi, hipotesis, dan determinasi dilakukan menggunakan data yang diolah dengan menggunakan program SPSS (Statistical Product and Service Solution) versi 16.0. Gambar 1 menunjukkan kerangka berpikir penelitian.

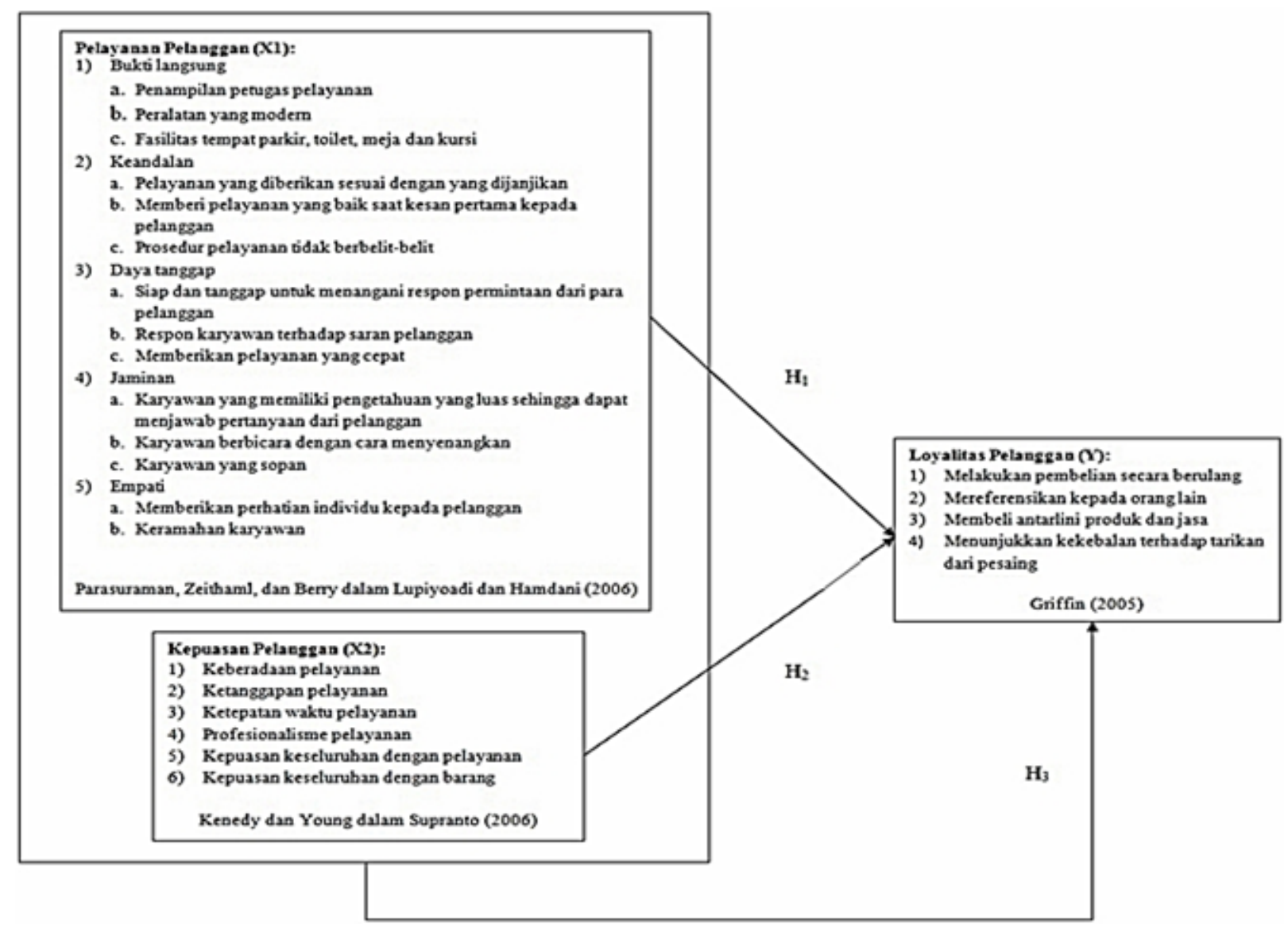

Gambar 1 Kerangka Pemikiran

HASIL DAN PEMBAHASAN

Berdasarkan t hitung sebesar 4,093. Setelah itu dicari Tabel distribusi t pada $\alpha=5 \%: 2=$ 2,5\% (uji 2 sisi), dengan derajat kebebasan (df) n-k-1 atau 100-2-1 = 97 (n adalah jumlah kasus dan $\mathrm{k}$ adalah jumlah variabel independen). Dengan pengujian 2 sisi (signifikansi $=0,025$ ), hasil untuk $\mathrm{t}$ 
Tabel diperoleh di Ms Excel dengan cara mengetik $=\operatorname{tinv}(0.05,97)$ dan diperoleh nilai sebesar 1,985. Kemudian membandingkan $t$ hitung dengan $t$ Tabel.

Ho diterima jika $-\mathrm{t}$ Tabel $\leq \mathrm{t}$ hitung $\leq \mathrm{t}$ Tabel

Ho ditolak jika -t hitung $<-t$ Tabel atau $t$ hitung $>t$ Tabel.

Nilai t hitung $>$ t Tabel $(4,093>1,985)$, maka Ho ditolak.

Oleh karena nilai t hitung $>$ t Tabel $(4,093>1,985)$, maka Ho ditolak. Artinya ada pengaruh secara signifikan antara pelayanan pelanggan dengan loyalitas pelanggan. Jadi dapat disimpulkan bahwa pelayanan pelanggan berpengaruh terhadap loyalitas pelanggan di 7-Eleven Buaran Jakarta.

Berdasarkan t hitung sebesar 3,010. Setelah itu dicari Tabel distribusi t pada $\alpha=5 \%: 2=$ 2,5\% (uji 2 sisi), dengan derajat kebebasan (df) n-k-1 atau 100-2-1 = 97 (n adalah jumlah kasus dan $\mathrm{k}$ adalah jumlah variabel independen). Dengan pengujian 2 sisi (signifikansi $=0,025$ ), hasil untuk $\mathrm{t}$ Tabel diperoleh di Ms Excel dengan cara mengetik $=\operatorname{tinv}(0.05,97)$ dan diperoleh nilai sebesar 1,985. Kemudian membandingkan $t$ hitung dengan $t$ Tabel.

Ho diterima jika $-\mathrm{t}$ Tabel $\leq \mathrm{t}$ hitung $\leq \mathrm{t}$ Tabel

Ho ditolak jika $-\mathrm{t}$ hitung $<-\mathrm{t}$ Tabel atau $\mathrm{t}$ hitung $>\mathrm{t}$ Tabel.

Nilai t hitung $>\mathrm{t}$ Tabel $(3,010>1,985)$, maka Ho ditolak.

Oleh karena nilai t hitung $>\mathrm{t}$ Tabel $(3,010>1,985)$, maka Ho ditolak. Artinya ada pengaruh secara signifikan antara kepuasan pelanggan dengan loyalitas pelanggan. Jadi dapat disimpulkan bahwa kepuasan pelanggan berpengaruh terhadap loyalitas pelanggan di 7-Eleven Buaran Jakarta.

Uji koefisien regresi secara bersama-sama (Uji F) digunakan untuk mengetahui apakah variabel independen $\left(\mathrm{X}_{1}, \mathrm{X}_{2}, \ldots . \mathrm{X}_{\mathrm{n}}\right)$ secara bersama-sama berpengaruh secara signifikan terhadap variabel dependen $(\mathrm{Y})$.

Tabel 1 Hasil F Hitung

\begin{tabular}{llrrrrr} 
ANOVA $^{\mathbf{b}}$ & & & & & & \\
\hline Model & & Sum of Squares & Df & Mean Square & F & \multicolumn{1}{l}{ Sig. } \\
\hline 1 & Regression & 677.015 & 2 & 338.507 & 8.698 & $.000^{\mathbf{a}}$ \\
& Residual & 3774.985 & 97 & 38.917 & & \\
& Total & 4452.000 & 99 & & & \\
\hline
\end{tabular}

a. Predictors: (Constant), Kepuasan Pelanggan, Pelayanan Pelanggan

b. Dependent Variable: Loyalitas Pelanggan

(Sumber: Pengolahan data, 2013)

Sebelum menghitung F Tabel, terlebih dahulu tentukan hipotesis dan tingkat signifikansi.

Ho: tidak ada pengaruh antara pelayanan pelanggan dan kepuasan pelanggan secara bersamasama terhadap loyalitas pelanggan.

Ha: ada pengaruh antara pelayanan pelanggan dan kepuasan pelanggan secara bersama-sama terhadap loyalitas pelanggan.

Tingkat signifikansi menggunakan $0,005(\alpha=5 \%)$.

Berdasarkan Tabel 2 diperoleh $\mathrm{F}$ hitung sebesar 8,698. Setelah itu menentukan $\mathrm{F}$ Tabel dengan menggunakan tingkat keyakinan 95\%, $\alpha=5 \%$, df 2 (n-k-1) atau 100-2-1 = 97 (n adalah jumlah 
kasus dan $\mathrm{k}$ adalah jumlah variabel independen). Hasil untuk $\mathrm{F}$ Tabel diperoleh di Ms Excel dengan cara mengetik = finv $(0.05,2,97)$ dan diperoleh nilai sebesar 3,090. Kemudian membandingkan $\mathrm{F}$ hitung dengan $\mathrm{F}$ Tabel. Ho diterima jika $\mathrm{F}$ hitung $\leq \mathrm{F}$ Tabel, dan Ho ditolak jika $\mathrm{F}$ hitung $>\mathrm{F}$ Tabel. Nilai F hitung $>$ F Tabel $(8,698>3,090)$, maka Ho ditolak.

Kesimpulannya, karena F hitung $>$ F Tabel $(8,698>3,090)$, maka Ho ditolak. Artinya, pelayanan pelanggan dan kepuasan pelanggan secara bersama-sama berpengaruh terhadap loyalitas pelanggan di 7-Eleven Buaran Jakarta

Tabel 2 Hasil Pengujian Hipotesis

\begin{tabular}{clcrl}
\hline \multirow{2}{*}{ No. } & Hipotesis & \multicolumn{3}{c}{ Pengujian Hipotesis } \\
\cline { 3 - 5 } & thitung & $\mathbf{f}_{\text {hitung }}$ & $\mathbf{t}_{\text {Tabel }} / \mathbf{f}_{\text {Tabel }}$ & Keputusan \\
\hline 1 & $\mathrm{X}_{1}$ dan $\mathrm{Y}$ & 4,093 & 1,985 & $\begin{array}{l}\text { Ho ditolak } \\
\text { Ha diterima }\end{array}$ \\
\hline 2 & $\mathrm{X}_{2}$ dan $\mathrm{Y}$ & 3,010 & 1,985 & $\begin{array}{l}\text { Ho ditolak } \\
\text { Ha diterima }\end{array}$ \\
\hline 3 & $\mathrm{X}_{1}, \mathrm{X}_{2}$ dan $\mathrm{Y}$ & 8,698 & 3,090 & $\begin{array}{l}\text { Ho ditolak } \\
\text { Ha diterima }\end{array}$ \\
\hline
\end{tabular}

(Sumber: Pengolahan data, 2013)

Hasil analisis determinasi Pelayanan Pelanggan terhadap Loyalitas Pelanggan dapat dilihat pada output Model Summary dari hasil analisis regresi sederhana pada Tabel 3. Berdasarkan output, diperoleh angka $\mathrm{R}^{2}$ ( $R$ Square) sebesar 0,146 . Hal ini menunjukkan bahwa persentase sumbangan pengaruh variabel independen (pelayanan pelanggan) terhadap variabel dependen (loyalitas pelanggan) sebesar $14,6 \%$. Atau variasi variabel independen yang digunakan dalam model (pelayanan pelanggan) mampu menjelaskan sebesar $14,6 \%$ variasi variabel dependen (loyalitas pelanggan). Sedangkan sisanya sebesar $85,4 \%$ dipengaruhi atau dijelaskan oleh variabel lain yang tidak dimasukkan dalam model penelitian ini.

Tabel 3 Analisis Determinasi Pelayanan Pelanggan terhadap Loyalitas Pelanggan

\section{Model Summary}

\begin{tabular}{lrrrr}
\hline Model & $\mathbf{R}$ & R Square & Adjusted R Square & Std. Error of the Estimate \\
1 & $.382^{\mathrm{a}}$ & .146 & .137 & 6.229
\end{tabular}

a. Predictors: (Constant), Pelayanan Pelanggan

(Sumber: Pengolahan data, 2013)

Hasil analisis determinasi Kepuasan Pelanggan terhadap Loyalitas Pelanggan dapat dilihat pada output Model Summary dari hasil analisis regresi sederhana pada Tabel 4. Berdasarkan output, diperoleh angka $\mathrm{R}^{2}$ ( $R$ Square) sebesar 0,085 . Hal ini menunjukkan bahwa persentase sumbangan pengaruh variabel independen (kepuasan pelanggan) terhadap variabel dependen (loyalitas pelanggan) sebesar $8,5 \%$. Atau variasi variabel independen yang digunakan dalam model (kepuasan pelanggan) mampu menjelaskan sebesar $8,5 \%$ variasi variabel dependen (loyalitas pelanggan). Sedangkan sisanya sebesar $91,5 \%$ dipengaruhi atau dijelaskan oleh variabel lain yang tidak dimasukkan dalam model penelitian ini. 
Tabel 4 Analisis Determinasi Kepuasan Pelanggan terhadap Loyalitas Pelanggan

Model Summary

\begin{tabular}{lrrrrr} 
Model & R & R Square & Adjusted R Square & Std. Error of the Estimate \\
\hline 1 & $.291^{\mathrm{a}}$ & .085 & .075 & 6.449 \\
\hline
\end{tabular}

a. Predictors: (Constant), Kepuasan Pelanggan

(Sumber: Pengolahan data, 2013)

Untuk hasil analisis determinasi antara dua variabel independen (pelayanan pelanggan dan kepuasan pelanggan) dengan variabel dependen (loyalitas pelanggan) output Model Summary dari hasil analisis regresi sederhana, diperoleh angka $\mathrm{R}^{2}(R$ Square) sebesar 0,152 . Hal ini menunjukkan bahwa persentase sumbangan pengaruh variabel independen (pelayanan pelanggan dan kepuasan pelanggan) terhadap variabel dependen (loyalitas pelanggan) sebesar 15,2\%. Atau variasi variabel independen yang digunakan dalam model (pelayanan pelanggan dan kepuasan pelanggan) mampu menjelaskan sebesar $15,2 \%$ variasi variabel dependen (loyalitas pelanggan). Sedangkan sisanya sebesar $84,4 \%$ dipengaruhi atau dijelaskan oleh variabel lain yang tidak dimasukkan dalam model penelitian ini. Gambar 2 berikut menunjukkan kerangka berpikir hasil pengujian hipotesis.

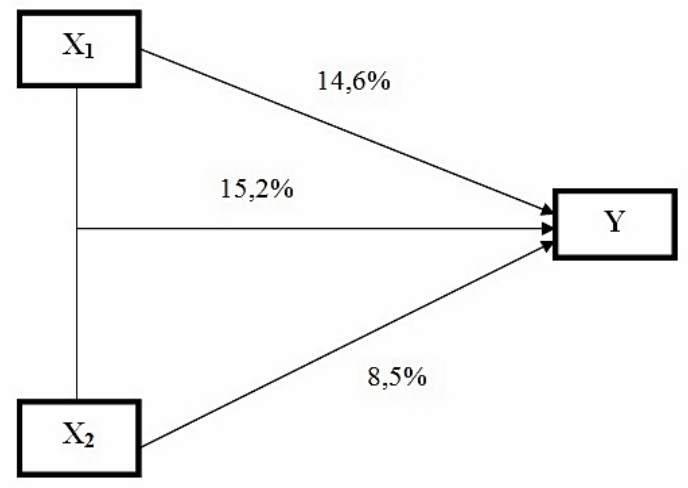

Gambar 2 Kerangka Hasil Pengujian Hipotesis (Sumber: Pengolahan data, 2013)

Ditinjau dari teori, dalam pelayanan pelanggan terkandung unsur-unsur seperti penampilan fisik, pemberian pelayanan sesuai yang dijanjikan, pelayanan yang cepat dan tepat, jaminan untuk menumbuhkan rasa percaya para pelanggan kepada perusahaan, serta pemahaman keinginan pelanggan. Penelitian ini ingin membuktikan apakah unsur pelayanan tersebut dapat memengaruhi loyalitas pelanggan 7-Eleven Buaran Jakarta. Setelah dilakukan penelitian, ternyata pelayanan pelanggan $\left(\mathrm{X}_{1}\right)$ berpengaruh signifikan terhadap loyalitas pelanggan $(\mathrm{Y})$. Hal ini dapat dibuktikan dari pengujian hipotesis yang menghasilkan $t$ hitung $(4,093)$ lebih besar dari $t$ Tabel $(1,985)$ yang dapat diungkapkan secara simbol $\mathrm{t}$ hitung 4,093 $>\mathrm{t}$ Tabel 1,985. Hasil uji hipotesis menunjukkan persentase pengaruh pelayanan pelanggan $\left(\mathrm{X}_{1}\right)$ terhadap loyalitas pelanggan $(\mathrm{Y})$ sebesar $14,6 \%$.

Selanjutnya, dari hasil penelitian terdapat pengaruh kepuasan pelanggan $\left(\mathrm{X}_{2}\right)$ yang signifikan terhadap loyalitas pelanggan (Y). Hal tersebut diperkuat dengan hasil pengujian hipotesis yang menghasilkan $\mathrm{t}$ hitung $(3,010)$ lebih besar dari t Tabel $(1,985)$ yang dapat diungkapkan secara simbol $\mathrm{t}$ hitung 3,010 $>\mathrm{t}$ Tabel 1,985 . Hasil uji hipotesis menunjukkan prosentase pengaruh $\mathrm{X}_{2}$ terhadap $\mathrm{Y}$ sebesar $8,5 \%$. 
Kemudian pengujian dua variabel independen, pelayanan pelanggan (X1) dan kepuasan pelanggan (X2), secara bersamaan juga menimbulkan pengaruh yang signifikan terhadap loyalitas pelanggan. Hal tersebut diperkuat dengan hasil pengujian hipotesis yang menghasilkan $\mathrm{F}$ hitung $(8,698)$ lebih besar dari $\mathrm{F}$ Tabel $(3,090)$ yang dapat diungkapkan secara simbol $\mathrm{F}$ hitung $8,698>\mathrm{F}$ Tabel 3,090. Hasil uji hipotesis $\mathrm{X}_{1}$ dan $\mathrm{X}_{2}$ menunjukkan persentase pengaruh terhadap $\mathrm{Y}$ sebesar $15,2 \%$. Hal ini menunjukkan bahwa pelayanan pelanggan dan kepuasan pelanggan berbanding lurus dalam memengaruhi loyalitas pelanggan. Makin baik pelayanan, maka makin tinggi kepuasan pelanggan dan pelanggan semakin loyal kepada 7-Eleven Buaran.

Dari semua hasil uji hipotesis, penelitian memperoleh satu temuan yang mengungkapkan bahwa sikap dan perilaku loyalitas pelanggan dapat ditimbulkan atau dipengaruhi oleh lebih dari satu atau beberapa variabel, seperti pelayanan pelanggan dan kepuasan pelanggan. Satu atau dua dari variabel tersebut harus memiliki mutu dan nilai kognitif (pengetahuan) serta nilai instrumental (terapan) yang dapat memberi kepuasan dan kepercayaan pelanggan pada pelayanan. Karena faktor kepercayaan pada pelayanan itulah, timbul ikatan emosional dalam diri konsumen terhadap lembaganya, dalam penelitian ini adalah 7-Eleven Buaran. Sehingga pada akhirnya hal tersebut memunculkan loyalitas dalam diri pelanggan.

\section{SIMPULAN}

Hasil analisis data penelitian menyimpulkan sebagai berikut. Pertama, berdasarkan uji $\mathrm{t}$ pelayanan pelanggan $\left(\mathrm{X}_{1}\right)$ dengan loyalitas pelanggan $(\mathrm{Y})$, $\mathrm{t}$ hitung 4,093 $>\mathrm{t}$ Tabel 1,985, maka Ho ditolak. Sedangkan berdasarkan analisis determinasi, terdapat nilai R Square sebesar 0,146. Artinya, terdapat pengaruh yang signifikan sebesar $14,6 \%$ antara pelayanan pelanggan terhadap loyalitas pelanggan di 7-Eleven Buaran Jakarta. Kedua, berdasarkan uji t kepuasan pelanggan $\left(\mathrm{X}_{2}\right)$ dengan loyalitas pelanggan $(\mathrm{Y}), \mathrm{t}$ hitung 3,010 > t Tabel 1,985, maka Ho ditolak. Sedangkan berdasarkan analisis determinasi, terdapat nilai R Square sebesar 0,085 . Artinya, terdapat pengaruh yang signifikan sebesar 8,5\% antara kepuasan pelanggan terhadap loyalitas pelanggan di 7-Eleven Buaran Jakarta. Ketiga, Berdasarkan uji $\mathrm{F}$ pelayanan pelanggan $\left(\mathrm{X}_{1}\right)$ dan kepuasan pelanggan $\left(\mathrm{X}_{2}\right)$ dengan loyalitas pelanggan (Y), menunjukkan bahwa F hitung 8,698 > F Tabel 3,090, maka Ho ditolak. Sedangkan berdasarkan analisis determinasi, terdapat nilai R Square sebesar 0,152. Artinya, terdapat pengaruh yang signifikan sebesar $15,2 \%$ antara kepuasan pelanggan terhadap loyalitas pelanggan di 7-Eleven Buaran Jakarta.

Berdasarkan hasil penelitian, dapat dikemukakan beberapa rekomendasi bagi perusahaan. Hendaknya para karyawan 7-Eleven Buaran meningkatkan kebersihan fasilitas meja dan kursi yang terdapat di 7-Eleven Buaran agar menjaga kenyamanan pelanggan, yaitu dengan cara langsung membersihkan meja dan kursi yang sudah kotor. Kemudian, hendaknya 7-Eleven Buaran meningkatkan kualitas pelayanan kepada pelanggan, yaitu dengan cara karyawan menyapa pelanggan yang datang ke 7-Eleven Buaran, memberikan reward kepada pelanggan atau pemberian paket makanan beserta minuman yang terus diperbarui setiap bulannya dengan harga khusus, potongan harga pada jam tertentu diberikan harga khusus pada suatu produk, serta pengadaan kotak saran dan kritik agar secara langsung mengetahui tanggapan pelanggan. Sebagai tambahan, pimpinan 7-Eleven Buaran disarankan agar memberikan pelatihan kepada para karyawan untuk meningkatkan kecepatan, kesigapan dan empati agar kepuasan pelanggan dan loyalitas pelanggan tetap terjaga. 


\section{DAFTAR PUSTAKA}

Effendy, O. U. (2007). Ilmu Komunikasi Teori dan Prakte. Bandung: Remaja Rosdakarya.

Griffin, J. D. (2005). Customer Loyalty: Menumbuhkan dan Mempertahankan Kesetiaan Pelanggan. Jakarta: Erlangga.

7-Eleven. (2013, April 10). About Us. Retrieved May 11, 2013, from history: http://corp.7-eleven.com.

Laksana, F. (2008). Manajemen Pemasaran: Pendekatan Prakti. Yogyakarta: Graha Ilmu.

Lupiyoadi, R. (2006). Manajemen Pemasaran Jasa Teori dan Praktik. Jakarta: Salemba Empat.

Mulyana, D. (2008). Ilmu Komunikasi Suatu Pengantar. Bandung: Remaja Rosdakarya.

Peter, J. P., dan Olson, J. C. (2000). Perilaku Konsumen dan Strategi Pemasaran. Jilid 2, Edisi 4. Jakarta: Erlangga.

Purwanto, D. (2006). Komunikasi Bisnis (3 ed.). Jakarta: Penerbit Erlangga.

Shim, T. A. (2003). Periklanan Promosi Aspek Tambahan Komunikasi Pemasaran Terpadu. Edisi Kelima. Jakarta: Erlangga.

Siagian, Y. M. (2005). Aplikasi Supply Chain Management dalam Dunia Bisnis. Jakarta: Grasindo.

Soliha, E. (2008). Analisis Industri Ritel di Indonesia. Jurnal Bisnis dan Ekonomi, 129.

Sumarwan, U. (2011). Perilaku Konsumen: Teori dan Penerapannya dalam Pemasaran. Jakarta: Ghalia Indonesia.

Supranto, J. (2006). Pengukuran Tingkat Kepuasan Pelanggan untuk Menaikkan Pangsa Pasar. Jakarta: Rineka Cipta. Jakarta: Rineka Cipta.

Thibaut, J. W., and Kelley, H. H. (1959). The Social Psychology of Groups. New York: John Wiley and Sons.

Tjiptono, F. (2007). Strategi Pemasaran. Yogyakarta: Andi.

West, R. (2008). Pengantar Teori Komunikasi: Teori dan Aplikasi. Jakarta: Salemba Humanika. 